\title{
Bio- and phytoremediation: plants and microbes to the rescue of heavy metal polluted soils
}

\author{
Sánchez-Jiménez Arantza ${ }^{1} \cdot$ Medrano-Roldán Hiram ${ }^{2} \cdot$ Kothe Erika $^{3} \cdot$ Mauricio Nahuam Chávez-Avilés ${ }^{4}$. \\ Juan I. Valiente-Banuet ${ }^{1}$. Grisel Fierros-Romero ${ }^{1}$
}

Received: 24 March 2021 / Accepted: 2 December 2021

Published online: 28 January 2022

(c) The Author(s) 2022 OPEN

\begin{abstract}
Bio- and phytoremediation, being encouraging terms implying the use of biological systems for cleansing purposes, have risen a worthy venture toward environmental restoration in discouraging scenarios, such as the augmentation of indestructible heavy metals. Hyperaccumulating plants and heavy metal resistant microbes own mechanisms embedded in their metabolism, proteins, and genes that confer them with "super characteristics" allowing them to assimilate heavy metals in order to amend polluted soils, and when combined in a symbiotic system, these super features could complement each other and be enhanced to overpower the exposure to toxic environments. Though xenobiotic pollution has been an object of concern for decades and physicochemical procedures are commonly carried out to offset this purpose, a "live" remediation is rather chosen and looked upon for promising results. A variety of benefits have been registered from symbiotic relationships, including plants teaming up with microbes to cope down with non-biodegradable elements such as heavy metals; but a carefully maneuvered interaction might signify a greater insight toward the application of bioremediation systems. These manipulations could consist of genetic engineering and/or additional supplementation of molecules and microbes. In the present study, a contemporary connection between plants and microbes involving their controlled management is summarized in a visionary display.
\end{abstract}

Keywords Bioremediation · Phytoremediation · Heavy metals · PGPMs · GMOs

\section{Introduction}

The unbridled extension and careless management of industrial, agricultural, and anthropogenic activities have derived into an overshoot of xenobiotic substances present in former healthy environments. Overage of contemporary pollutants leads to concerning implications covering an extensive invasion of said substances, triggering long-term implications on human and environmental health; a subject of matter requiring immediate remedy, as well as new clean-up technologies.

Whereas some polluting agents can be easily treated, some elements cannot be degraded, which is the case with heavy metals. Their environmental accumulation favors their dispersion through water and soil, compromising the life of the organisms. In this sense, human health is mainly threatened by lead, cadmium, mercury, and arsenic exposure [30]. These metals are comprised

Grisel Fierros-Romero, griselfierrosromero@gmail.com | ${ }^{1}$ School of Engineering and Sciences, Tecnológico de Monterrey, Campus Querétaro, Avenida Epigmenio González No. 500, 76130 San Pablo, Querétaro, Mexico. ${ }^{2}$ Tecnologico Nacional de Mexico/Campus Durango., 1830 Felipe Pescador Ave. Z.C., 34080 Durango, Dgo., Mexico. ${ }^{3}$ Microbial Communication, Institute of Microbiology, Friedrich Schiller University Jena, Neugasse 25, 07745 Jena, Germany. ${ }^{4}$ Laboratorio de Bioquímica y Biología Molecular, División de Ingeniería Bioquímica, Tecnológico Nacional de México Campus Ciudad Hidalgo, Av. Ing. Carlos Rojas Gutiérrez No. 2120 Fracc. Valle de La Herradura C.P., 61100 Hidalgo, Michoacán, México. 
in a hazardous category and are visualized as primary threats due to their toxicity to both humans and plants [13]. The gravity of this type of contamination signifies tissue bioaccumulation in living organisms that brings about a biomagnification in the trophic levels, not mentioning the trascendental diseases that heavy metals provoke and their outlet into water consume featuring their involvement in water cycles [32].

Outdated methods against heavy metal pollution consist of landfilling, which is the construction of cells usually built of cement or steel, to confine the contaminants with barriers [18]. Besides being an uneconomical choice, the "solution" means a temporary cover up. Furthermore, the risks implied in secondary pollution and workers integrity have lessened the attractiveness on maintaining the execution of these processes. Other efficiency-questioned methods include physicochemical separation, membrane separation, solvent extraction, ion exchange, and other physicochemical and electrochemical methods [9]. Wetlands are also commonly employed for heavy metal removal through reactions of sedimentation, flocculation, absorption, co-precipitations, cation and anion exchange, precipitation, and oxidation/reduction; along with microbiological activity and plant uptake [47]. According to Brar et al. [9], bioremediation was already the most adopted method of decontamination with a $32 \%$ of preference next to chemical treatments $(14 \%)$, in situ thermal treatment $(6 \%)$, soil vapor extraction (6\%), thermal desorption $(5 \%)$, solidification/stabilization (5\%), permeable reactive barriers (4\%), flushing (3\%), off gas treatment (3\%), soil washing (3\%), phytoremediation (3\%), multi-phase extraction (2\%), pump and treat (2\%), vitrification ( $2 \%)$, and others (10\%).

Compared to traditional methods of remediation implying a physicochemical mix of procedures, the use of "living" remediation is rather chosen. Though heavy metals cannot be fully removed, particular organisms contribute to their neutralization in order to reduce their harmful effect on the environment [64].

Bioremediation is therefore defined as the elimination of contaminants using biological systems by their break down, transformation or degradation. Modalities of the process are split into in situ and ex situ remediation. Ex situ remediation consists of the transportation of contaminated matter to another site for further treatment, while in situ remediation implies the procedures to be performed in the place of origin. [32].

Budding from this biotechnological subject, phytoremediation and more elaborated cleansing techniques also take place to this purpose. The upgrowth of bioremediation techniques utilizing plants with microbes is the outcome of the pursuit for alternative methods with clean-up purposes that has lead to the development of bioaugmentation or rhizoremediation [35].

Microorganisms (comprehending bacteria, yeast, fungi, and even archaeon) and plants are the imperative tools required to remediate industrial wastes such as heavy metals, pesticides, toxic chemical fertilizers, among others [33, 86], due to their resemblance as biological catalysts in a bioremediation system [84] arranged by suitable components to fix contaminated environments, meaning microorganisms that are able to take up and transform heavy metals, as well as suited plants to remove and restrain metals from the ground [33].

Though heavy metals appear to be complex pollutants to handle, bioremediation is an attractive method to mend soils contaminated by them, and furthermore, the combination of both microorganisms and plants is an approach to ensure a more efficient clean-up [13].

Consequently, the handling of plants and their associated microorganisms to restore heavy metal polluted settings is a field of expansion that provides beneficial aspects corresponding to cost-effectiveness, sustainability, and environmental implications [1]. The information provided in the present review has a bioremediation approach in soils.

\section{Heavy metals}

Heavy metals belong to a group of elements characterized by a high atomic weight and density, corresponding to above $5 \mathrm{~g} / \mathrm{cm}^{3}$ [52]. From 90 elements that occur naturally, 21 are non-metals, 16 are light-metals, and 53 are designated as heavy metals [89]. These elements can be categorized in two main groups: the ones that could be required in minimal quantities by some organisms (including $\mathrm{Co}$, $\mathrm{Cu}, \mathrm{Fe}, \mathrm{Mn}, \mathrm{Mo}, \mathrm{Ni}, \mathrm{V}$, and $\mathrm{Zn}$ ) and those that are considered as entirely menacing ( $\mathrm{Pb}, \mathrm{Cd}, \mathrm{Hg}$, and $\mathrm{As})$ [13].

Natural liberation of these elements occurs by volcanic activity, comets, erosion, and the weathering of minerals. Natural states of heavy metals are not ready for plant uptake or available for living organisms; but anthropogenic activities involving battery production, mining, explosive manufacturing, use of pesticides, phosphate fertilizers, sewage irrigation, steel and electroplating industries, textiles and wood preservation, among others; lead to the excessive liberation of these elements and contribute to their accumulation and dispersion. These activities put in risk all life forms when exceeding normal levels, leading to threatening consequences in their composition [5].

These elements are endured in different ways, depending on the organism they face. Beginning with human vulnerability, heavy metals are conferred with an 
intriguing toxicity according to their bioavailability and their lipid solubility. Molecular affections resulting from heavy metal exposure consist of their attachment to the binding sites of proteins; removing other molecules and causing cellular malfunction [32]. The incomplete $d$ orbitals of most heavy metals allow them to form complex compounds in the cells, leading to toxic effects [52]. Although the intracellular concentration of metal ions can sometimes be controlled by protein families in the cells, such as the ABC, $P$-type ATPases or RND proteins; their effect on living organisms can be counterproductive. Major affections are caused by dermal contact, ingestion or inhalation, wherein absorption of heavy metals induces the transport of these elements and distributes them through body tissues, persisting in organs such as bones, liver, or kidneys [32].

Highlighting the overriding elements of concern and their fatalities, Arsenic is a carcinogenic, cardiovascular and neurobehavioral disorder trigger; besides, intoxication by this element is surprisingly ordinary. As for Cadmium, exposure to this metal derives into lung and stomach cancer, osteoporosis, chromosomal aberrations and damage, as well as liver, kidney, lungs, and heart dysfunction. Lead, however, causes anemia and conditions related to kidney and liver illness, as well as to the reproductive, gastrointestinal, and central nervous system maladies. Least but not less important, Mercury, a remarkable toxic topic, is known to develop neurotoxic effects and is absorbed by the gastrointestinal tract to reach the brain, kidneys, liver, and nervous tissue [32], a threatening element to adipose tissue.

In a vegetative point of view, metal ions are known to damage cell membranes, inhibit enzymatic and photosynthetic activities, and drive the generation of reactive oxygen species in plants. These stress effects make plants more susceptible to climate change, as well as plant productivity [65].

As for microbes, bacteria and fungi can take up elements that might not be vital for microbial metabolism from the soil and store them, such as $\mathrm{Cd}, \mathrm{Ni}$, or $\mathrm{Cu}$ [33]. $\mathrm{Cd} \& \mathrm{Hg}$ are not required for biological functions [67], yet they can be accumulated, as well as Au, Cs, and U [64]. But on the other hand, some other metals could be required in their metabolic processes as essential micronutrients in trace concentrations, like $\mathrm{Co}, \mathrm{Cr}, \mathrm{Ni}, \mathrm{Fe}, \mathrm{Mn}$, and $\mathrm{Zn}$ [53].

Since they cannot be destroyed or decomposed, bioremediation principally involves processes such as reducing the solubility of these metals through $\mathrm{pH}$ and redox reactions modulation, mobilization, and immobilization, as well as the confinement of the contaminants from polluted environments [28], among other mechanisms furtherly described.
Though the profile that is built around heavy metals seems discouraging, the literature proposes a transformation ratio, by microorganisms alone, of $27 \%$ for $\mathrm{Cr}, 20 \%$ for $\mathrm{Co}, 31 \%$ for $\mathrm{Cd}, 22 \%$ for $\mathrm{Pb}, 7 \%$ for $\mathrm{Ni}, 5 \%$ for Zinc, and about $18 \%$ for $\mathrm{As} \& \mathrm{Cd}$ [64]. If an additional setting is built where these microorganisms team up with the proper plants, a powerful combination is set on board, but understanding their individual capacities first is in order.

\section{Phytoremediation and hyperaccumulating plants}

The plants that are utilized for heavy metal removal in phytoremediation usually possess a rapid growth rate, high biomass production, extensive root system, and high heavy metal tolerance [46]. These plants are defined as hyperaccumulators. In order to point out a hyperaccumulator, it needs to meet a higher concentration than $0.1 \%$ for $\mathrm{Al}, \mathrm{As}, \mathrm{Co}, \mathrm{Cr}, \mathrm{Cu}, \mathrm{Ni}$, and $\mathrm{Se}$; higher than $0.01 \%$ for $\mathrm{Cd}$, and higher than $1.0 \%$ for Zinc, in their shoot [6]. They can transport and accumulate from 100 to 1000 times higher metal concentrations than non-accumulating ones without suffering apparent phytotoxic effects.

Some mechanisms involved in metal detoxification in plants consist of plant cell wall binding, active transport of ions into cell vacuoles, intracellular complexation with peptide ligands such as phytochelatins (PCs) and metallothioneins (MTs), and sequestration of metal-siderophore complexes in root apoplasm or soil [40]. Others consist of exudate production, one of the most critical strategies in plants to tolerate high metal concentrations [40], especially low molecular weight organic acids (LMWOAs) like citric, oxalic, malic, and succinic acid [48], to detoxify As, $\mathrm{Cd} \& \mathrm{~Pb}$ [49]. Naturally involved proteins and molecules in plant metabolism when in heavy metal exposure are summarized in Table 1.

Plants provide numerous ways of opposing contaminants, as shown in Table 2.

Hyperaccumulating plants of toxic heavy metals are distributed in about 45 plant families, including Scrophulariaceae, Lamiaceae, Fabaceae, Asteraceae, Euphorbiaceae, and Brassicaceae, but about 500 plant species have been used for this purpose [4]. Examples of hyperaccumulating plants (and their remarkable accumulation capacities in $\mathrm{mg} / \mathrm{kg}^{-1}$ ) include Corrigiola cheiradenia (2110 of As), Euphorbia cheiradenia (1138 of Pb), and Azolla pinnata (740 of Cd) [83]. However, more commonly known hyperaccumulators include the sunflower (Helianthus annuus), brown mustard (Brassica juncea), or duckweed (Lemna minor); in addition with a growing protagonism of legumes for the task [36]. 
Table 1 Proteins involved in heavy metal tolerance and resistance in plants

\begin{tabular}{llll}
\hline Type of Proteins & Function & $\begin{array}{l}\text { Elements } \\
\text { involved }\end{array}$ & Reference \\
\hline NRAMP & Transporters & $\begin{array}{c}\text { Se, As, Cd, } \\
\mathrm{Ni}, \mathrm{Zn}, \mathrm{Mn},\end{array}$ \\
$\begin{array}{l}\text { OPT } \\
\text { MATE } \mathrm{Fe}\end{array}$ & \\
MATE & & \\
ZIP ZTR/IRT & & \\
HMA4 & & \\
PC & Detoxification & \\
MT & & \\
GSH & & \\
PAL & & \\
OXML & & \\
LMWC & & \\
\hline
\end{tabular}

NRAMP, Natural resistance-associated macrophage protein, OPT, oligopeptide transporters, MATE, multidrug and toxic compound extrusion, HMA4, heavy metal ATPase 4, PC, phytochelatins, MT, metallothionein, $G S H$, glutathione, $P A L$, phenylalanine ammonialyase, oxML, oxy monolignol, $L M W X$, low molecular weight compounds

Ricinus communis L. \& Helianthus annuus, for instance, have been used for $\mathrm{Cd}$ removal, as well as $\mathrm{Zn}$. Multimetal removal can also be performed, an example is Suaeda salsa with Cu, Zn, As, \& Cr (Zhang 2019) and Pennisetum giganteum with $\mathrm{Cu}, \mathrm{Pb}$, and $\mathrm{Ni}[76]$.

\section{Heavy metal bioremediation mechanisms in microorganisms}

Microbes may own biochemical or molecular mechanisms to bear up against contaminants. In a biochemical appraisal, microorganisms are able to carry out processes of acidification, precipitation, chelation, and complexation. Resistance activity can also be described in mechanisms as cell surface biosorption, cell transporting systems via active efflux pumping of metals out of the cell, sequestration of metals in intracellular compartments, exclusion of metal chelates into the extracellular space, and enzymatic redox reactions to convert a metal ion into a non-toxic or less toxic state [40]. Due to the multiple oxidation states that inorganic compounds display, redox reactions occur to reach the least hazardous stage, where commonly, the higher oxidation state, the less soluble [64], therefore, more dangerous. However, their ability to degrade or restrain and transform pollutants (according to their organic or inorganic nature depends on the suitability of environmental conditions for their growth and metabolism, which include conditions such as temperature, $\mathrm{pH}$, moisture [86], as well as density and type of charge in soil colloids [46], soil aeration, mineral composition and microbial activity [44].

Potential microorganisms with remarkable transforming capacities include Cupriavidus metallidurans, Pseudomonas aeruginosa, Pseudomonas putida (referring to bacteria), Aspergillus versicolor, Aspergillus fumigatus, Aspergillus tereus, Penicillum chrysogenum (referring to fungi), Candida utilis, Rhodotorula mucilaginosa, Saccharomyces cerevisiae (referring to yeast), and Phylum Crenarchaeota sp. \& Phanerochaete chrysosporium (referring to archaea) [64].

Regarding a molecular perspective, some microorganisms own heavy metal resistance genes and/or proteins that provide them of unique characteristics to endure these elements. Examples are provided in Tables 3 and 4.

Table 2 Bioremediation mechanisms in plants

\begin{tabular}{|c|c|c|}
\hline Mechanism & Description & References \\
\hline $\begin{array}{l}\text { Phytoaccumulation } \\
\text { or Phytoextrac- } \\
\text { tion }\end{array}$ & Pollutant take up in plant biomass, taken from the soil through the roots into upper plant components & $\begin{array}{l}{[46,71,2,13,} \\
40,56,24]\end{array}$ \\
\hline Phytofiltration & $\begin{array}{l}\text { Represents three types of filtration in plants: Rhizofiltration (use of roots), blastofiltration (use of seed- } \\
\text { lings), and caulofiltration (use of excised plant shoots) }\end{array}$ & \\
\hline Rhizofiltration & $\begin{array}{l}\text { Elimination of toxic substances from groundwater through root filtration by terrestrial and aquatic } \\
\text { plants }\end{array}$ & \\
\hline Phytostimulation & Use of exudates from plant roots to stimulate microbial activity and enhance it & \\
\hline Phytostabilization & $\begin{array}{l}\text { Immobilization of metal by plants, reducing their bioavailability; turning them into less harmful and } \\
\text { preventing their spread in the environment }\end{array}$ & \\
\hline Phytovolatization & $\begin{array}{l}\text { Pollutants taken from the soil are transformed into volatile forms and transpired into the atmosphere, } \\
\text { mainly } \mathrm{Hg} \& \mathrm{Se}\end{array}$ & \\
\hline Phytodegradation & Breakdown of organic contaminants into non-hazardous forms by plant enzymes & \\
\hline Detoxification & Involves processes such as adsorption, chelation, transformation, and inactivation of metals & \\
\hline
\end{tabular}


Table 3 Protein superfamilies that contribute to heavy metal resistance in microorganisms

\begin{tabular}{|c|c|c|c|}
\hline Protein family & Characteristics & Heavy metal resistance & References \\
\hline RND Transenvelope efflux & Transport proteins constituted by MFP, RND, and OMF & $\mathrm{Ni}, \mathrm{Co}, \mathrm{Zn}, \mathrm{Cd}, \mathrm{Ag}$ & $\begin{array}{c}{[11,29,39,52,} \\
53,70,54,46]\end{array}$ \\
\hline P-type ATPases & Bidirectional transport of metal ions & $\begin{array}{l}\text { Ion substrates such as } \mathrm{H}^{+}, \mathrm{Na}^{+}, \mathrm{K}^{+} \\
\mathrm{Mg}^{2+}, \mathrm{Ca}^{2+}, \mathrm{Cu}^{+}, \mathrm{Ag}^{+}, \mathrm{Zn}^{2+}, \mathrm{Cd}^{2+}\end{array}$ & \\
\hline CDF Efflux proteins & Cation diffusor facilitator driven by chemiosmotic forces & $\mathrm{Zn}, \mathrm{Cd}, \mathrm{Co}, \mathrm{Fe}$ & \\
\hline $\mathrm{ABC}$ transporters & Uptake and efflux of metal ions & $\mathrm{Mn}, \mathrm{Zn}, \mathrm{Ni}, \mathrm{Fe}$ & \\
\hline
\end{tabular}

$O M F$, Outer membrane factors, MFP, membrane fusion protein family, RND, resistance, nodulation, and cell division

Table 4 Examples of genes and proteins that provide heavy metal resistance to microorganisms

\begin{tabular}{|c|c|c|c|c|c|}
\hline Gene & Protein & Type & Microorganism & Heavy metal resistance & References \\
\hline nсcTXH & nccCBA & $\begin{array}{l}\text { RND } \\
\text { RND }\end{array}$ & C. metallidurans & $\mathrm{Ni}, \mathrm{Co}$ & {$[55]$} \\
\hline cnrYXH & $\mathrm{CZCCBA}$ & & C. metallidurans & $\mathrm{Co}, \mathrm{Zn}, \mathrm{Cd}$ and $\mathrm{Ni}$ & {$[54]$} \\
\hline cus & CusCFBA proteins & RND & Escherichia coli & $\mathrm{Co} \& \mathrm{Ag}$ & {$[50]$} \\
\hline mer & $\begin{array}{l}\text { Mer proteins (MerA, MerB, } \\
\text { MerC, MerD, MerE, MerT, } \\
\text { MerP) }\end{array}$ & Mercuric reductase & $\begin{array}{l}\text { Proteobacteria, Firmicutes, } \\
\text { Actinobacteria }\end{array}$ & $\mathrm{Hg}$ & [3] \\
\hline CadA \& CadC & CadA \& CadC & P-Type ATPase & Staphyloccocus aureus & $\mathrm{Cd}, \mathrm{Cu}, \mathrm{Pb}, \mathrm{Zn}$ & {$[25]$} \\
\hline $\begin{array}{l}\text { NikA, NikB, } \\
\quad \text { NikC, NikD, } \\
\text { NikE }\end{array}$ & NikA, NikB, NikC, NikD, NikE & ABC Transporters & Archaea \& fungi & $\mathrm{Ni}$ & {$[68]$} \\
\hline NixA gene & $\begin{array}{l}\text { High-affinity nickel-trans- } \\
\text { port protein NixA }\end{array}$ & $\begin{array}{l}\text { Nickel-dependent regula- } \\
\text { tory protein }\end{array}$ & Helicobacter pylori & $\mathrm{Ni}$ & {$[23]$} \\
\hline HoxN gene & HoxN protein & $\begin{array}{l}\text { High-affinity nickel trans- } \\
\text { port protein }\end{array}$ & $\begin{array}{l}\text { Alcaligenes eutrophus, } \\
\text { Yersinia pestis, Ralstonia } \\
\text { eutropha }\end{array}$ & $\mathrm{Ni} /$ Co resistance & {$[10]$} \\
\hline yohM gene & yohM protein & $\mathrm{Ni} / \mathrm{Co}$ efflux system & E. coli & $\mathrm{Ni} /$ Co resistance & {$[27]$} \\
\hline ars operon & ArsA, ArsB, ArsC & ATPase & $\begin{array}{l}\text { P. putida, Bacillus subtilis, } P \text {. } \\
\text { aeruginosa, E. coli }\end{array}$ & Arsenic resistance & [7] \\
\hline
\end{tabular}

\section{Plants team up with microbes}

Plant-associated microbial diversity, and overall hostmicrobiome interactions, is a product of evolutionary and ecological events $[73,77]$. They are so intimately related that it is almost impossible to separate them as components of the ecosystem, even in modern research, they are nominated as eco-holobionts [77]. Since microbes are ubiquitous, almost any other organism is colonizable, and although this party can become both positive and negative, it is most beneficial and symbiotic [77]. With plants, complex communities are formed in an effort to achieve a healthy state of the environment [34].

Broadly, microbes protect and stimulate plants, while plants provide them with nutrients; but having so much potential belonging to fascinating organisms, this symbiotic interest cannot only happen for survival purposes, but for greater benefits, including heavy-metal bioremediation.
Individual microbial and plant properties that promote heavy metal bioremediation have already been mentioned. In an environmental turn, hyperaccumulating plants alone already imply an approach to remove contaminants, but due to high heavy metal toxicity, the association with specialized microorganisms improves the chances of conquering this target. When these organisms interact with one another, new and enhanced processes occur to arrest heavy metals, leading to multiple cleansing options, where the use of phytoremediation and microbes are a key in providing a multielement remediation option for anthropologically contaminated landscapes [62].

In order to reach this objective and to operate as a directed bioremediation symbiotic system, specialized microbes promote plant activity and survival. They are categorized as Plant Growth-Promoting Microorganisms (PGPMs). 


\section{Plant growth-promoting microorganisms (PGPMs)}

A variety of microbes are considered beneficial for plants, like Plant Growth-Promoting Bacteria (PGPB) and Rhizobacteria (PGPR), Nitrate Fixation Bacteria (NFB), Arbuscular Mycorrhizal Fungi (AMF), and Siderophore Producing Bacteria (SPB), mainly. They are capable of influencing plant activity in terms of root exudate composition modification, growth enhancement [81], and systemic resistance induction to subsequent pathogen attack [15], among other reactions shown in Table 5.

Plant growth promotion is influenced by the plant's rhizosphere, composed of the overall plant roots and its exudates [85] including sugars, amino acids, organic acids, fatty acids, phenols, enzymes, and flavonoids, and lead by PGPR with the production of phytohormones like cytokinins, ethylene, and gibberellic, jasmonic, salicylic or abscisic acid $[45,59,17]$. PGPR have the ability to affect post-embryonic root development too. They can alter cell division and differentiation in the primary root, root hair, and lateral roots; they can also promote shoot growth, but they do not only stimulate root growth and development [85].

Among root exudate communication with microorganisms, flavonoids play a key component in plant-microbe interactions such as mycorrhiza formation, the establishment of legume-rhizobia symbiosis [80], AMF spore germination, hyphal growth, differentiation, and root colonization in AMF-plant interactions [63].

Other processes, derived from quorum sensing, also occur in plant-microbe interactions. For instance, Acylated Homoserine Lactones (AHLs) control bacterial traits such as symbiosis, virulence, competence, conjugation, mobility, sporulation, biofilm, and antibiotic production [19], and when recognized by plants, modulation of tissuespecific gene expression, plant growth homeostasis, and defense responses are triggered [14].

In a bioremediation aspect, PGPB possess single or multiple traits of heavy metal toxicity alleviation, alteration of metal availability, production of siderophores, biochelation, fixation of nitrogen, and solubilization of mineral nutrients [41]. Most of the bacteria located in the rhizosphere of plants are naturally tolerant to environmental contaminants, which is why they play an essential role in organic and heavy metal removal [56].

Table 5 summarizes PGPM activity.

Commonly used and widely studied bacteria to enhance plant growth and activities include Pseudomonas, Enterobacter, Arthrobacter, Glucanoacetobacterium, Flavobacterium, Beijerinkia, Klebsiella, Erwinia, Bacillus, Serratia, among others [4].

\section{Plant-microbe interaction for bioremediation purposes}

In order to survive in toxic and nutrient-limited environments, many plants interact with rhizospheric and rootassociated microbes [1], event from where this interaction's bioremediation purpose originates from. The potential resistant or stimulating microbial rhizosphere communities emerge and develop during plant growth in the same polluted areas [35]. However, the insertion of a microbial strain for xenobiotic degrading activities on plant seeds to further colonize the root and remain on the root system can also be performed [56].

The plant communicates with the microbes during its growth through root exudates and diverse molecules to stimulate the survival and action of bacteria, enhancing pollutant confinement, transformation or degradation [35]. These molecules act as chelating agents and can enhance the phytoavailability of pollutants [1], as well as their mobility [56]. For this reason, such microorganisms' performance is a vital role in phytoremediation systems.

The use of plants for the treatment of contaminated soils with heavy metals or radionuclides like sewage sludge, power plants, or nuclear power reactors wastes [28] is a more conventional approach in bioremediation, and the combination of microorganisms and plants is an approach that ensures more efficient clean-up [13]. Having this in mind, we can present the following definitions:

\subsection{Bioaugmentation}

The bioaugmentation method improves the degradation and enhances the transformation rate of xenobiotics by the insertion of specific microorganisms [35]. Unlike phytoremediation, which occurs when plant enzymes establish the degradation of pollutants, the attenuation or bioaugmentation occurs when the microbial population performs such degradation. The re-introduction of protective microbes also benefits plant development by creating optimal conditions for crop growth under harsh conditions, hence reducing water, fertilizer, and pesticide use [34].

When a suitable rhizospheric strain is introduced into a suitable plant, the bacteria might settle on the root along with the indigenous population, enhancing the bioremediation process. Then, the efficient root-colonizing pollutant bacteria would profit from the growing root system, spreading through the soil [35]. However, consortia of bacteria often cause the degradation of a pollutant, mainly because several bacterial populations degrade pollutants more efficiently than a single strain [56]. 
Table 5 Role of PGPMs in plant growth and bioremediation

\begin{tabular}{|c|c|c|c|}
\hline Mechanism & Type & Effect & References \\
\hline Siderophore production & SPB & $\begin{array}{l}\text { Siderophores as metal chelators increase the solubility of nutrients, } \\
\text { enhancing metal accumulation in plant tissues and solubilizing } \\
\text { unavailable forms of heavy metals by complexation }\end{array}$ & {$[16,74]$} \\
\hline Phosphate solubilization & PGPM & $\begin{array}{l}\text { Insoluble metal sulfides can precipitate } \\
\text { When phosphorus is unavailable for plants: } \\
\text { PSMs convert phosphorus to a soluble form for plants } \\
\text { PSB inhabit the rhizosphere and supply phosphorus to the plant }\end{array}$ & $\begin{array}{l}{[40]} \\
{[56]}\end{array}$ \\
\hline ACC Deaminase production & PGPR & $\begin{array}{l}\text { It allows plants to mitigate abiotic stress conditions and stimulates } \\
\text { plant growth by breaking ACC (ethylene precursor that inhibits } \\
\text { plant growth), developing the plant root system }\end{array}$ & $\begin{array}{l}{[56]} \\
{[22]}\end{array}$ \\
\hline IAA production & PGPR & $\begin{array}{l}\text { Production and release of auxins such as IAA, stimulate the growth } \\
\text { of the root system and protect the plant from abiotic stress }\end{array}$ & [78] \\
\hline ROS balancing & PGPR & $\begin{array}{l}\text { ROS regulates the transition from proliferation to differentiation } \\
\text { independent of auxin and cytokinins, and PGPR may alter ROS } \\
\text { balance within the root resulting in growth and developmental } \\
\text { changes }\end{array}$ & [72] \\
\hline Endogenous mechanisms manipulation & PGPR & $\begin{array}{l}\text { Bacteria manipulate the hosts' inner mechanisms to regulate post- } \\
\text { embryonic root development to alter root growth }\end{array}$ & [85] \\
\hline Production of biochelators & PGPB & Production of organic acid or biosurfactants & [40] \\
\hline Defense mechanism induction & PGPM & $\begin{array}{l}\text { PGPMs stimulate plant growth indirectly via the induction of } \\
\text { defense mechanisms against phytopathogens }\end{array}$ & [40] \\
\hline Quorum sensing & PGPM & $\begin{array}{l}\text { Diketopiperazines (DKPs) and N-Acyl-homoserine lactones (AHLs) } \\
\text { compounds are produced by numerous bacterial species } \\
\text { involved in quorum sensing }\end{array}$ & [85] \\
\hline Metal bioavailability & PGPM & $\begin{array}{l}\text { Change in metal bioavailability in the soil through various bio- } \\
\text { chemical and molecular mechanisms }\end{array}$ & [40] \\
\hline Metal toxicity immobilization and transformation & AMF & $\begin{array}{l}\text { Metal induced toxicity reduction, metal availability change through } \\
\text { alteration of soil } \mathrm{pH} \text {, and metal translocation affection }\end{array}$ & $\begin{array}{l}{[12]} \\
{[65]} \\
{[40]}\end{array}$ \\
\hline Plant activity enhancement & AMF & Boosting plant growth and nutrient uptake & $\begin{array}{l}{[58]} \\
{[12]}\end{array}$ \\
\hline VOC emission (Acetoin and 2,3-Butanediol) & PGPB & $\begin{array}{l}\text { Establish communication with plants, trigger plant defense, and } \\
\text { growth promotion mechanisms by enabling host plants to colo- } \\
\text { nize nutrients or soils }\end{array}$ & [40] \\
\hline VOC emission & PGPB & $\begin{array}{l}\text { Impact to act as bioprotectants (induced systemic resistance, ISR), } \\
\text { biopesticides (antibiotic functions), and phytostimulators (trig- } \\
\text { gering hormonal networks) }\end{array}$ & $\begin{array}{l}{[69]} \\
{[82]} \\
{[91]} \\
{[40]}\end{array}$ \\
\hline VOC emission & PGPB & $\begin{array}{l}\text { Ability to affect mycelium growth and sporulation of different } \\
\text { fungal species (Ammonia, Butyrolactones, Hydrogen cyanide, } \\
\text { Phenazine-1-carboxylic acid, or Alcohols) }\end{array}$ & $\begin{array}{l}{[31]} \\
{[40]}\end{array}$ \\
\hline Signaling molecules & AMF \& Rhizobia & $\begin{array}{l}\text { Synthesis of Myc (AMF) and Nod (Rhizobia) factor can modulate } \\
\text { root system architecture, such as stimulation of lateral root } \\
\text { branching, the formation of new organs, and nodule }\end{array}$ & $\begin{array}{l}{[57]} \\
{[40]}\end{array}$ \\
\hline Fertility improvement & NFB & $\begin{array}{l}\text { Enhance biological Nitrogen and improve the fertility of polluted } \\
\text { soils for plant growth by catalyzing the reduction of atmospheric } \\
\mathrm{N}_{2} \text { to biologically available ammonium }\end{array}$ & $\begin{array}{l}{[40]} \\
{[51]}\end{array}$ \\
\hline Production of Biosurfactants & PGPR & $\begin{array}{l}\text { Microbial metabolite production that facilitates metal mobilization } \\
\text { by complexation of metals in their nonionic forms to remove } \\
\text { them from surfaces, acting as soil washing agents }\end{array}$ & [74] \\
\hline Microbial EPS Production & PGPR & $\begin{array}{l}\text { EPS can sequester metal ions by their functional groups such as } \\
\text { carboxyl, phosphoric, amine, and hydroxyl groups that are natu- } \\
\text { rally negatively charged to form organo-metallic complexes }\end{array}$ & [74] \\
\hline
\end{tabular}

ACC, 1-Aminocyclopropane-1-carboxylate, IAA, Indole-3-Acetic Acid, PSMs, Phosphate-Solubilizing Microorganisms, PSB, Phosphate-Solubilizing Bacteria, ROS, Reactive Oxygen Species, SPB, iderophore Producing Bacteria, VOC, Volatile Organic Compounds, NFB, Nitrogen Fixating Bacteria, EPS, Extracellular Polysaccharide Substances 


\subsection{Rhizoremediation}

When phytoremediation and bioaugmentation combine, rhizoremediation takes place. During this process, exudates derived from plant roots can improve efficiency of phytoremediation [34] and spread the bacteria through the soil. Substantial degradation of pollutants is due to the microbes living in the rhizosphere, dominated by Gram-negative rods such as Pseudomonas spp. [35], but the first studies toward the degradation of compounds in the rhizosphere were mainly focused on herbicides and pesticide remotion [35], rather than heavy metal remediation. For instance, it has been proven to work against trichloroethylene (TCE), polycyclic aromatic hydrocarbons (PAHs), and polychlorinated biphenyls (PCBs) [35], and for PCB rhizoremediation, sugar beet was inoculated with $P$. fluorescens [8]. Providing an example with heavy metals, $\mathrm{Cd}+$ was rhizoremediated using Astragalus sinicus and Mesorhizobium huakuii [79].

Retaking the importance of the individual mechanisms previously presented, the gathering of these qualities and their potential for environmental engineering purposes will be understood.

Probably the main mechanism of bioremediation by microbes is chelation. Plants and microbes can release organic chelating compounds such as metal-binding compounds, organic acid anions, siderophores, biosurfactants, and metallophores [75], to take metals ions and prevent them to be resorpted [20]. Metallophores are LMWOLs released from microorganisms that can regulate intracellular metal concentrations to avoid toxicity or maintain appropriate concentrations for their growth [40]. Organic acids involved in rhizospheric processes also promote heavy metal detoxification and mobilization or solubilization in soil [65]. Bioaccumulation is characterized by the metabolic activities involving the use of MTs and PCs for intracellular sequestration, extracellular precipitation, metal accumulation, and complex formation [20]; these mechanisms are useful for plant metal toxicity reduction and uptake [41].
As for metal immobilization mechanisms, plants teamed up with microorganisms can promote the precipitation of radionuclides and toxic metals by enzymatic catalysis or reduction processes [61]. In precipitation, bacteria protect the host plant against the inhibitory effect of heavy metals [40]. Besides the use of enzymes, insoluble mineral forms of radionuclides, and metals can be immobilized by bacterial Fe oxidation or interactions between inorganic acids such as hydrogen sulfide, bicarbonate, and phosphate [92]. These last components interact with dissolved metals and form insoluble precipitates. SRB can also influence in this mechanism, where bacteria can solubilize minerals, promote plant growth, and immobilize metals in soil in phytostabilization [92].

In complexation, extracellular polysaccharide substances (EPS) secreted by plant-associated microbes form a protective barrier against harmful effects through metal biosorption through mechanisms like ion exchange, adsorption, and precipitation [26]. Microbial biosorption consists of the use of living or dead biomass and their components to remove or recover metals and metalloids. Biosorption also contributes to heavy metal speciation, defined as the identification and quantification of metals to determine their bioavailability and therefore, their toxicity in terms of $\mathrm{pH}$, temperature or time; complying information regarding their specie, form or phases in which they occur [5]. EPSs are a key point for biosorption, and most bacteria produce them. These exopolymers are able to create strong bonds with trace elements and form organo-metallic complexes. Also, biofilms (communities of microorganisms) produce EPS and adsorpt heavy metals in a better way than the planktonic species. EPS are composed by polysaccharides, mucopolysaccharides, humic substances, and proteins. Quorum sensing defines the production of EPS by two systems, the Lasl/ LasR and Rh1l/Rh1R. Microorganisms such as Rhizobium melitoti, Pseudomonas sp., Cupriavidus paulucus, Azotobacter sp., are reported to produce EPS [74].

When speaking of heavy metal speciation, these may be organized according to their biosorption behaviors in different $\mathrm{pH}$ (Table 6).

Table 6 Classes of metal species and their $\mathrm{pH}$ biosorption behaviors

\begin{tabular}{|c|c|c|c|c|}
\hline Class & $\mathrm{pH}$ bonding & Characteristics & Examples & References \\
\hline 1 & $\begin{array}{l}\text { Bonds strongly in a neutral } \\
\text { medium }\end{array}$ & $\begin{array}{l}\text { Taken up from biological } \\
\text { substrates at } \mathrm{pH}<2\end{array}$ & $\mathrm{Al}^{3+}, \mathrm{Cu}^{2+}, \mathrm{Cd}^{2+}, \mathrm{Cr}^{3+}, \mathrm{Co}^{2+}, \mathrm{Fe}^{3+}, \mathrm{Ni}^{2+}, \mathrm{Pb}^{2+}, \mathrm{Zn}^{2+}$ & {$[43,42,90]$} \\
\hline II & $\begin{array}{l}\text { Bond strongly at low } \mathrm{pH} \text { but } \\
\text { weakly at } \mathrm{pH}>5\end{array}$ & $\begin{array}{l}\text { Binding due to protonated } \\
\text { nitrogen atoms of amine } \\
\text { groups }\end{array}$ & $\mathrm{PtCl}_{4}^{2-}, \mathrm{CrO}_{4}^{2-} \& \mathrm{SeO}_{4}^{2}$ & \\
\hline III & Binding independent to $\mathrm{pH}$ & $\begin{array}{l}\text { Biosorption due to covalent } \\
\text { bonds between the metals } \\
\text { and ligands on cell surface }\end{array}$ & $\mathrm{Ag}^{+}, \mathrm{Hg}^{2+} \& \mathrm{AuCl}_{4}^{-}$ & \\
\hline
\end{tabular}

SN Applied Sciences 
Heavy metal speciation improves their biosorption while profiling the conditions at which they can be adsorpted, facilitating the manipulation and enhancement of the process.

Continuing with immobilization processes, alkalinization affects stability in soil. For instance, AMF and bacteria can absorb metals through substrate alkalinization activity by releasing $\mathrm{OH}$ - to activate nitrate uptake by microbes and reduce metal phytoavailability in the rhizosphere by secreting glomalin [21], an insoluble metal-sorbing glycoprotein that reduces metal mobility or sequesters metals [88].

On the other hand, in terms of acidification, $\mathrm{pH}$ represents an essential aspect for soil remediation effectivity, as well as the mobility, and solubility of metals [66]. Mobilized metals increase $\mathrm{pH}$, and plant roots secrete hydrogen ions that can displace heavy metal cations adsorbed in soil, which leads to rhizosphere acidification; however, root exudates lower $\mathrm{pH}$ [40].

In a briefly summarized picture, Fig. 1 describes the benefits of microbes teaming up with plants.

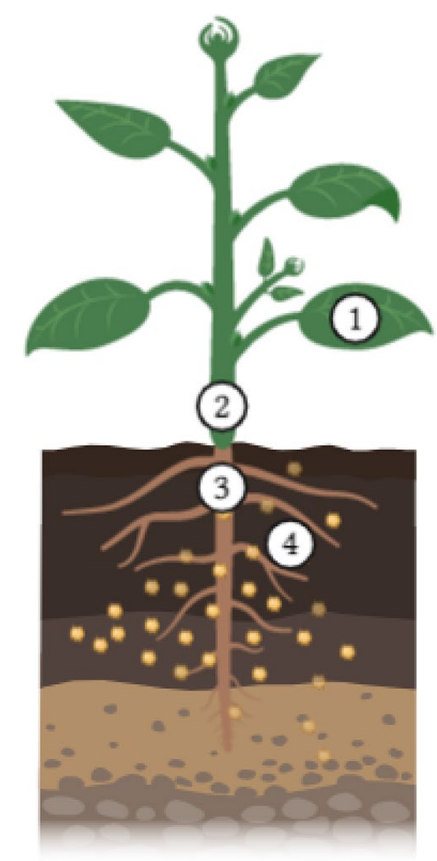

Fig. 1 PGPMs enhance phytoremediation processes in plants by plant biomass expedition (1), bioaccumulation or metal translocation facilitation from soil to root (2), translocation or transport from root to shoot tissues (3), increase in heavy metal availability in soil by phytoextraction or decrease in metal availability in soil in phytostabilization (4)

\section{Visionary super powers}

Phytoremediation assistance includes PGPMs, heavy metal accelerators, transgenic plants, nanoparticles [37], chelating agents, and even biochar addition [76]. Phytoremediation expands an "old process" that occurs naturally, but in a manipulated and conscious way, manual supplementation and genetic engineering could contribute to the development of a perfect bioremediation system. Once that Bioremediation mechanisms proper of plants and microorganisms are fully understood, their controlled combination can be standardized to be applied in situ or ex situ. Edited plants, microorganisms and enzymes to degrade harmful substances and facilitate remediation processes, as well as creating biomarkers to detect contamination of a particular type, are a field of expansion. All of these aspects, combined, can create a potential weapon against contamination of non-biodegradable elements, as well as organic contaminants.

Also, PGPMs, by displaying numerous plant benefits, suggest that the identification of the responsible genes could be selected from these microbes, which deliver future insights to discover preferential associations between specific genes and phytobeneficial traits. Initially, the attractive characteristics to be taken and exploited with bioremediation efforts consisted on the plant's growth rate, leading to a focus of identifying the responses of high biomass expedition, but lately, this interest leans more strongly to metal accumulating genotypes.

There are four main approaches related to the development of genetically engineered microorganisms with Bioremediation focus: Bioaffinity bioreporter sensor applications in chemical sensing, end point analysis and toxicity reduction; bioprocess development, monitoring and control; enhancement of affinity and enzyme specificity; and construction and pathway regulation [87].

Table 7 summarizes genetically engineered organisms with heavy metal remediation purposes.

Though Genetic Engineering sounds like a lovely bet to modify and increase organism's bioremediative characteristics, there are limiting factors for their development. For instance, revising microbes, such microorganisms are suggested to include suicidal genes to avoid horizontal gene transfer with native microbes in order to prevent the native microbial population displacement. Also, modified microbes cannot be liberated into polluted areas, and one of the reasons includes the hostile environment that this signifies for them [87]. In the case of bioaugmented plants, these must coexist with its natural rhizobacteria. However, the perfection and continuous research about these mechanisms is still necessary for new proposed solutions. 
Table 7 Examples of genetically engineered organisms with heavy metal remediation characteristics in modern times

\begin{tabular}{|c|c|c|c|}
\hline Organism & Gene/Protein & Bioremediation Trait & References \\
\hline E. coli & $\begin{array}{l}\text { ArsR } \\
\text { Manganese transporter } \\
\text { MT } \\
\text { MerR } \\
\text { Phytochelatin Synthase (SpPCS) } \\
\text { Cd Transporter (MntA) } \\
\text { Lead-binding peptide }\end{array}$ & $\begin{array}{l}\mathrm{As}(\mathrm{III}), \mathrm{As}(\mathrm{V}), \mathrm{Cd}^{2+}, \mathrm{Pb}^{2+}, \mathrm{Hg}^{2+} \\
\text { Synthesis of } \mathrm{PC} \text { and } \mathrm{MT}\end{array}$ & {$[90,87,60]$} \\
\hline Saccharomyces cerevisiae & $\begin{array}{l}\text { MT tandem repeats } \\
\text { Arabidopsis thaliana Phytochelatin Syn- } \\
\text { thase (AtPCS) } \\
\text { Arsenic transporters Fps1p and Hxt7p } \\
\text { Pb transporting P1-type ATPases }\end{array}$ & $\begin{array}{l}\mathrm{Cd}^{2+}, \mathrm{As} \mathrm{Pb}^{2+} \\
\mathrm{PC} \\
\mathrm{MT}\end{array}$ & \\
\hline P. putida & Monkey MT $\propto$ tandem repeats & $\begin{array}{l}\mathrm{MT} \\
\mathrm{Cd}^{2+}\end{array}$ & \\
\hline Mesorhizobium huakuii subsp. Rengei & Arabidopsis thaliana PCS; PCSAt & PC & \\
\hline Rhodopseudomonas palustris & $\begin{array}{l}\text { pEBZ141 from Alcaligenes eutrophus } \\
\text { Mercury transport system and MT }\end{array}$ & $\mathrm{Cr}, \mathrm{Hg}$ transport, $\mathrm{MT}, \mathrm{Hg}^{2+}$ & \\
\hline Pseudomonas fluorescens OS8 & $\begin{array}{l}\text { MerR } \\
\text { CadC } \\
\text { ZntR } \\
\text { Pmer } \\
\text { PcadA } \\
\text { PzntA }\end{array}$ & $\mathrm{Cd}, \mathrm{Pb}, \mathrm{Hg}, \mathrm{Zn}$ & \\
\hline Deinococcus radiodurans & merA & $\mathrm{Hg}(\mathrm{II})$ & \\
\hline Arabidopsis thaliana & $\begin{array}{l}\text { MerC } \\
\text { AdPCs1-2-3 } \\
\text { ZmUBP15-16-19 } \\
\text { PCs1 } \\
\text { CsCCoAOMT } \\
\text { YSL } \\
\text { SsMT2 }\end{array}$ & $\mathrm{Hg}, \mathrm{Cd}, \mathrm{Na}$ & \\
\hline
\end{tabular}

As a closure, what comes after phytoremediation activities is as important as the remediation itself. This last procedure also needs to encourage more research to achieve optimal remediation processes. Harvesting of plants used in phytoremediation of heavy metals creates heavy contaminated bio-waste [37], but processes to treat them are proposed, including heat treatment, incineration, pyrolysis, gasification, or carbonization [37]. In these processes, fly ash is released, containing heavy metals and discharging them. The higher the temperature, the higher vaporization of the $\mathrm{HM}$, where the remaining ashes are bioleached [37].

During pyrolysis, biomass is decomposed at elevated temperatures, resulting with biochar, bio-oil and pyrolysis gases. However, heavy metals enter biochar and the distribution is similar to incineration. In this process, the temperature is a key factor to decrease risk potential. An additional use of the resulting biochar could include the plant-stimulation and biochemical improvement of soil during phytoremediation of heavy metals.
As it can be perceived, part of an efficient plant-microbe team up involves multiple variables toward a futuristic insight of environmental amendment.

\section{Conclusion}

Modern bioremediation does not longer include plants and/or microbes solely, but proposes a mixture of both organisms along with biochemical, ecological and genetic engineering aspects, along with nanotechnology. The use of biotechnology for the restoration of polluted sites is a modern alternative to contamination cleansing. Urges related to pollution and its consequences lead to new options and technological adaptations, where the combination of microorganisms and plants is an exciting update to this task. In addition, microbial and/or plant efficiency can be improved with genetic engineering assistance. Deeper research still needs to be conducted to clarify doubts about the safety of GMO release; in the meantime, the gathering of scientific 
disciplines makes the building of new tools an intriguing step toward this goal. Whereas phytoremediation and bioremediation using microorganisms provide numerous possibilities for contamination removal, the combination of both is translated into an enhanced process. Plant-microbe interaction has been present in nature in different ways, especially in a rhizospheric aspect, and the forms in which these interactions favor each other are quite impressive. A close-up to understanding these interactions has opened doors to further opportunities where the use of PGPMs and hyperaccumulating plants manipulated in a specific way could mean the primary tool for the success of a combined cleansing system. It provides a high number of perspectives and applications to develop more robust bioremediation activity toward heavy metal contamination, and of course, other sources of contamination. Since modern approaches keep on surging, genetically engineered plants, microbes, or enzymes could be right around the corner for huge phytoremediation applications. Advances of this nature imply the manipulation of traits such as chelating properties or new technological derivatives like nano-phytoremediation and biochar-assisted phytoremediation. The understanding and discovery of the presented mechanisms can lead us toward a restoration future, where the recipe of the perfect system involving hyperaccumulating plants, microbial genes and enzymes, hormone and chelating agents supplementation among multiple mechanisms used as ingredients, could be cooked.

Acknowledgements This project was supported by Grant No. 1007547 from CONACyT, Mexico.

\section{Declarations}

Conflict of interest The authors declare that there are no conflict of interests.

Open Access This article is licensed under a Creative Commons Attribution 4.0 International License, which permits use, sharing, adaptation, distribution and reproduction in any medium or format, as long as you give appropriate credit to the original author(s) and the source, provide a link to the Creative Commons licence, and indicate if changes were made. The images or other third party material in this article are included in the article's Creative Commons licence, unless indicated otherwise in a credit line to the material. If material is not included in the article's Creative Commons licence and your intended use is not permitted by statutory regulation or exceeds the permitted use, you will need to obtain permission directly from the copyright holder. To view a copy of this licence, visit http://creativecommons. org/licenses/by/4.0/.

\section{References}

1. Abhilash PC, Powell JR, Singh HB, Singh BK (2012) Plant-microbe interactions: novel applications for exploitation in multipurpose remediation technologies. Trends Biotechnol 30(8):416-420. https://doi.org/10.1016/j.tibtech.2012.04.004

2. Ali H, Khan E, Sajad MA (2013) Phytoremediation of heavy metals-concepts and applications. Chemosphere 91(7):869-881. https://doi.org/10.1016/j.chemosphere.2013.01.075

3. Anton A, Weltrowski A, Haney CJ, Franke S, Grass G, Rensing C, Nies DH (2004) Characteristics of zinc transport by two bacterial cation diffusion facilitators from Ralstonia metallidurans $\mathrm{CH} 34$ and Escherichia coli. J Bacteriol 186(22):7499-7507

4. Ashraf MA, Hussain I, Rasheed R, lqbal M, Riaz M, Arif MS (2017) Advances in microbe-assisted reclamation of heavy metal contaminated soils over the last decade: a review. J Environ Manag 198:132-143. https://doi.org/10.1016/j.jenvman.2017.04.060

5. Ayangbenro AS, Babalola OO (2017) A new strategy for heavy metal polluted environments: a review of microbial biosorbents. Int J Environ Res Public Health 14(1):94. https://doi.org/10.3390/ ijerph14010094

6. Baker A, Brooks R (1989) Terrestrial Higher Plants Which Hyperaccumulate Metallic Elements, A Review of Their Distribution, E. Ecol. Phytochem. Biorecovery. 1

7. Ben Fekih I, Zhang C, Li YP, Zhao Y, Alwathnani HA, Saquib Q, Rensing C, Cervantes C (2018) Distribution of arsenic resistance genes in prokaryotes. Front Microbiol 9:2473. https://doi.org/10. 3389/fmicb.2018.02473

8. Brazil GM, Kenefick L, Callanan M, Haro A, de Lorenzo V, Dowling DN, O'Gara F (1995) Construction of a rhizosphere pseudomonad with potential to degrade polychlorinated biphenyls and detection of bph gene expression in the rhizosphere. Appl Environ Microbiol 61(5):1946-1952

9. Brar SK, Verma M, Surampalli RY, Misra K, Tyagi RD, Meunier N, Blais JF (2006) Bioremediation of hazardous wastes-a review. Pract Period Hazard Toxic Radioact Waste Manag 10(2):59-72. https://doi.org/10.1061/(asce)1090-025x(2006)10:2(59)

10. Boyd ES, Barkay T (2012) The mercury resistance operon: from an origin in a geothermal environment to an efficient detoxification machine. Front Microbiol 3:349. https://doi.org/10. 3389/fmicb.2012.00349

11. Campbell PM, Smith GD (1986) Transport and accumulation of nickel ions in the cyanobacterium Anabaena cylindrica. Arch Biochem Biophys 244(2):470-477

12. Chang Q, Guo W, Pan L, Wang QF, Zhou XN, Yang L, Li E (2017) Effects of Arbuscular Mycorrhizal fungi on the growth and uptake of $\mathrm{La}$ and $\mathrm{Pb}$ by maize grown in $\mathrm{La}$ and $\mathrm{Pb}$-contaminated soil. Huan Jing Ke Xue 38(9):3915-3926. https://doi.org/ 10.13227/j.hjkx.201702041

13. Chibuike GU, Obiora SC (2014) heavy metal polluted soils: effect on plants and bioremediation methods. Appl Environ Soil Sci 2014:752708. https://doi.org/10.1155/2014/752708

14. Daniels R, Vanderleyden J, Michiels J (2004) Quorum sensing and swarming migration in bacteria. FEMS Microbiol Rev 28(3):261-289. https://doi.org/10.1016/j.femsre.2003.09.004

15. Dardanelli MS, Manyani H, González-Barroso S, RodríguezCarvajal MA, Gil-Serrano AM, Espuny MR, López-Baena FJ, Bellogín RA, Megías M, Ollero FJ (2010) Effect of the presence of the plant growth promoting rhizobacterium (PGPR) Chryseobacterium balustinum Aur9 and salt stress in the pattern of flavonoids exuded by soybean roots. Plant Soil 328(1):483493. https://doi.org/10.1007/s11104-009-0127-6

16. Dimkpa CO, Svatos A, Dabrowska P, Schmidt A, Boland W, Kothe $E$ (2008) Involvement of siderophores in the reduction of metal-induced inhibition of auxin synthesis in Streptomyces spp. Chemosphere 74(1):19-25. https://doi.org/10.1016/j. chemosphere.2008.09.079

17. Doornbos RF, Geraats BP, Kuramae EE, Van Loon LC, Bakker PA (2011) Effects of jasmonic acid, ethylene, and salicylic acid signaling on the rhizosphere bacterial community of 
Arabidopsis thaliana. Mol Plant Microbe Interact 24(4):395407. https://doi.org/10.1094/MPMI-05-10-0115

18. EPA REACH IT (2004) Remediation and characterization innovative technologies. Information snapshots: Technologies by type. http://www.epareachit.org/ Feb. 15, 2004.

19. Fuqua C, Parsek MR, Greenberg EP (2001) Regulation of gene expression by cell-to-cell communication: acyl-homoserine lactone quorum sensing. Annu Rev Genet 35:439-468. https:// doi.org/10.1146/annurev.genet.35.102401.090913

20. Gadd G (2004) Microbial influence on metal mobility and application for bioremediation. Geoderma 122:109-119. https://doi.org/10.1016/j.geoderma.2004.01.002

21. Giasson P, Karam A, Jaouich A (2008) Arbuscular Mycorrhizae and alleviation of soil stresses on plant growth. Springer, Dordrecht, pp 99-134

22. Glick BR (2014) Bacteria with ACC deaminase can promote plant growth and help to feed the world. Microbiol Res 169(1):30-39. https://doi.org/10.1016/j.micres.2013.09.009

23. Gutierrez JC, Amaro F, Martin-Gonzalez A (2009) From heavy metal-binders to biosensors: ciliate metallothioneins discussed. BioEssays 31(7):805-816

24. Govere EM (2021) Environmental phytoremediation and analytical technologies for heavy metal removal and assessment. In: Ricroch A, Chopra S, Kuntz M (eds) Plant biotechnology. Springer, Cham

25. Hebbeln P, Eitinger T (2004) Heterologous production and characterization of bacterial nickel/cobalt permeases. FEMS Microbiol Lett 230(1):129-135

26. Hou W, Ma Z, Sun L, Han M, Lu J, Li Z, Mohamad OA, Wei G (2013) Extracellular polymeric substances from copper-tolerance Sinorhizobium meliloti immobilize Cu2+. J Hazard Mater 261:614-620. https://doi.org/10.1016/j.jhazmat.2013.06.043

27. Icgen B, Yilmaz F (2016) Use of cadA-specific primers and DNA probes as tools to select cadmium biosorbents with potential in remediation strategies. Bull Environ Contam Toxicol 96(5):685693. https://doi.org/10.1007/s00128-016-1767-x

28. Jain S, Arnepalli DN (2019) Biominerlisation as a remediation technique: a critical review. In: Stalin V, Muttharam M (eds) Geotechnical characterisation and geoenvironmental engineering. Springer, Singapore, pp 155-162

29. Jarrell KF, Sprott GD (1982) Nickel transport in Methanobacterium bryantii. J Bacteriol 151(3):1195-1203

30. Jarup L (2003) Hazards of heavy metal contamination. Br Med Bull 68:167-182. https://doi.org/10.1093/bmb/ldg032

31. Kai M, Haustein M, Molina F, Petri A, Scholz B, Piechulla B (2009) Bacterial volatiles and their action potential. Appl Microbiol Biotechnol 81(6):1001-1012. https://doi.org/10.1007/ s00253-008-1760-3

32. Kapahi M, Sachdeva S (2019) Bioremediation options for heavy metal pollution. J Health Pollut 9(24):191203. https://doi.org/ 10.5696/2156-9614-9.24.191203

33. Kothe E (2009) UMBRELLA against heavy metals. Microbiologist coordinates new EU research collaboration. Retrieved from: http://uni-jena.de/PM090903_Umbrella-lang-en.pdf

34. Kothe E, Turnau K (2018) Editorial: Mycorrhizosphere communication: mycorrhizal fungi and endophytic fungus-plant interactions. Front Microbiol 9:3015. https://doi.org/10.3389/fmicb. 2018.03015

35. Kuiper I, Lagendijk EL, Bloemberg GV, Lugtenberg BJ (2004) Rhizoremediation: a beneficial plant-microbe interaction. Mol Plant Microbe Interact 17(1):6-15. https://doi.org/10.1094/mpmi. 2004.17.1.6

36. Kushwaha P, Lal P (2021) A review of advances in bioremediation of heavy metals by microbes and plants. http://anrcm.org/ wp-content/uploads/2021/10/09-P-Kushwaha.pdf
37. Liu Z, Tran K (2021) A review on disposal and utilization of phytoremediation plants containing heavy metals. Retrieved from: https://www.sciencedirect.com/science/article/pii/S014765132 1009337

38. Lohmeyer M, Friedrich CG (2004) Nickel transport in Alcaligenes eutrophus. Arch Microbiol 149:130-135

39. Lundie LL Jr, Yang HC, Heinonen JK, Dean SI, Drake HL (1988) Energy-dependent, high-affinity transport of nickel by the acetogen Clostridium thermoaceticum. J Bacteriol 170(12):5705-5708

40. Ma Y, Oliveira RS, Freitas H, Zhang C (2016) Biochemical and molecular mechanisms of plant-microbe-metal interactions: relevance for phytoremediation. Front Plant Sci 7:918. https:// doi.org/10.3389/fpls.2016.00918

41. Ma Y, Rajkumar M, Freitas H (2009) Improvement of plant growth and nickel uptake by nickel resistant-plant-growth promoting bacteria. J Hazard Mater 166(2-3):1154-1161. https://doi.org/ 10.1016/j.jhazmat.2008.12.018

42. Mack C, Wilhelmi B, Duncan JR, Burgess JE (2007) Biosorption of precious metals. Biotechnol Adv 25(3):264-271. https://doi.org/ 10.1016/j.biotechadv.2007.01.003

43. Madrid Y, Cámara C (1997) Biological substrates for metal preconcentration and speciation. TrAC, Trends Anal Chem 16(1):3644. https://doi.org/10.1016/s0165-9936(96)00075-1

44. Magnuson ML, Kelty CA, Kelty KC (2001) Trace metal loading on water-borne soil and dust particles characterized through the use of split-flow thin-cell fractionation. Anal Chem 73(14):3492-3496. https://doi.org/10.1021/ac0015321

45. Malamy JE (2005) Intrinsic and environmental response pathways that regulate root system architecture. Plant Cell Environ 28(1):67-77. https://doi.org/10.1111/j.1365-3040.2005. 01306.x

46. Marques APGC, Rangel AOSS, Castro PML (2009) Remediation of heavy metal contaminated soils: phytoremediation as a potentially promising clean-up technology. Crit Rev Environ Sci Technol 39(8):622-654. https://doi.org/10.1080/10643 380701798272

47. Matagi S, Swai D, Mugabe R (1998) A review of heavy metal removal mechanisms in wetlands. Afr J Trop Hydrobiol Fish. https://doi.org/10.4314/ajthf.v8i1.1386

48. Meier S, Alvear M, Borie F, Aguilera P, Ginocchio R, Cornejo P (2012) Influence of copper on root exudate patterns in some metallophytes and agricultural plants. Ecotoxicol Environ Saf 75:8-15. https://doi.org/10.1016/j.ecoenv.2011.08.029

49. Mleczek M, Kozlowska M, Kaczmarek Z, Chadzinikolau T, Golinski $\mathrm{P}$ (2012) Influence of $\mathrm{Ca} / \mathrm{Mg}$ ratio on phytoextraction properties of Salix viminalis I. The effectiveness of $\mathrm{Cd}, \mathrm{Cu}, \mathrm{Pb}$, and $\mathrm{Zn}$ bioaccumulation and plant growth. Int J Phytoremediation 14(1):75-88. https://doi.org/10.1080/15226514.2011.573824

50. Mulrooney SB, Hausinger RP (2003) Nickel uptake and utilization by microorganisms. FEMS Microbiol Rev 27(2-3):239-261

51. Navarro-Noya YE, Hernández-Mendoza E, Morales-Jiménez J, Jan-Roblero J, Martínez-Romero E, Hernández-Rodríguez C (2012) Isolation and characterization of nitrogen fixing heterotrophic bacteria from the rhizosphere of pioneer plants growing on mine tailings. Appl Soil Ecol 62:52-60. https://doi. org/10.1016/j.apsoil.2012.07.011

52. Nies DH (1999) Microbial heavy-metal resistance. Appl Microbiol Biotechnol 51(6):730-750. https://doi.org/10.1007/s002530051 457

53. Nies DH (2000) Heavy metal-resistant bacteria as extremophiles: molecular physiology and biotechnological use of Ralstonia sp. $\mathrm{CH} 34$. Extremophiles 4(2):77-82

54. Nies DH (2003) Efflux-mediated heavy metal resistance in prokaryotes. FEMS Microbiol Rev 27(2-3):313-339 
55. Nucifora G, Chu L, Misra TK, Silver S (1989) Cadmium resistance from Staphylococcus aureus plasmid pl258 cadA gene results from a cadmium-efflux ATPase. Proc Natl Acad Sci U S A 86(10):3544-3548. https://doi.org/10.1073/pnas.86.10.3544

56. Ojuederie OB, Babalola OO (2017) Microbial and plant-assisted bioremediation of heavy metal polluted environments: a review. Int J Environ Res Public Health 14(12):1504. https://doi.org/10. 3390/ijerph14121504

57. Olah B, Briere C, Becard G, Denarie J, Gough C (2005) Nod factors and a diffusible factor from arbuscular mycorrhizal fungi stimulate lateral root formation in Medicago truncatula via the DMI1/DMI2 signalling pathway. Plant J 44(2):195-207. https:// doi.org/10.1111/j.1365-313X.2005.02522.x

58. Orlowska E, Przybylowicz W, Orlowski D, Mongwaketsi NP, Turnau K, Mesjasz-Przybylowicz J (2013) Mycorrhizal colonization affects the elemental distribution in roots of Ni-hyperaccumulator Berkheya coddii Roessler. Environ Pollut 175:100-109. https://doi.org/10.1016/j.envpol.2012.12.028

59. Osmont KS, Sibout R, Hardtke CS (2007) Hidden branches: developments in root system architecture. Annu Rev Plant Biol 58:93-113. https://doi.org/10.1146/annurev.arplant.58.032806. 104006

60. Ozyigit II, Can H, Dogan I (2021) Phytoremediation using genetically engineered plants to remove metals: a review. Environ Chem Lett 19:669-698. https://doi.org/10.1007/ s10311-020-01095-6

61. Payne AN, Dichristina TJ (2006) A rapid mutant screening technique for detection of technetium [Tc(VII)] reduction-deficient mutants of Shewanella oneidensis MR-1. FEMS Microbiol Lett 259(2):282-287. https://doi.org/10.1111/j.1574-6968.2006. 00278.x

62. Phieler R, Merten D, Roth M, Büchel G, Kothe E (2015) Phytoremediation using microbially mediated metal accumulation in Sorghum bicolor. Environ Sci Pollut Res 22(24):19408-19416. https://doi.org/10.1007/s11356-015-4471-1

63. Poulin MJ, Bel-Rhlid R, Piche Y, Chenevert R (1993) Flavonoids released by carrot (Daucus carota) seedlings stimulate hyphal development of vesicular-arbuscular mycorrhizal fungi in the presence of optimal $\mathrm{CO} 2$ enrichment. J Chem Ecol 19(10):2317-2327. https://doi.org/10.1007/BF00979666

64. Pratush A, Kumar A, Hu Z (2018) Adverse effect of heavy metals $(\mathrm{As}, \mathrm{Pb}, \mathrm{Hg}$, and $\mathrm{Cr}$ ) on health and their bioremediation strategies: a review. Int Microbiol 21(3):97-106. https://doi. org/10.1007/s10123-018-0012-3

65. Rajkumar M, Sandhya S, Prasad MN, Freitas H (2012) Perspectives of plant-associated microbes in heavy metal phytoremediation. Biotechnol Adv 30(6):1562-1574. https://doi.org/10. 1016/j.biotechadv.2012.04.011

66. Richards BK, Steenhuis TS, Peverly JH, McBride MB (2000) Effect of sludge-processing mode, soil texture and soil $\mathrm{pH}$ on metal mobility in undisturbed soil columns under accelerated loading. Environ Pollut 109(2):327-346. https://doi.org/ 10.1016/s0269-7491(99)00249-3

67. Roane TM, Pepper IL (1999) Microbial responses to environmentally toxic cadmium. Microb Ecol 38(4):358-364

68. Rodrigue A, Effantin G, Mandrand-Berthelot MA (2005) Identification of rcnA (yohM), a nickel and cobalt resistance gene in Escherichia coli. J Bacteriol 187(8):2912-2916

69. Ryu CM, Farag MA, Hu CH, Reddy MS, Kloepper JW, Pare PW (2004) Bacterial volatiles induce systemic resistance in Arabidopsis. Plant Physiol 134(3):1017-1026. https://doi.org/10. 1104/pp.103.026583

70. Sandrin TR, Chech AM, Maier RM (2000) A rhamnolipid biosurfactant reduces cadmium toxicity during naphthalene biodegradation. Appl Environ Microbiol 66(10):4585-4588
71. Sarma H (2011) Metal hyperaccumulation in plants: a review focusing on phytoremediation technology. J Environ Sci Technol. https://doi.org/10.3923/jest.2011.118.138

72. Schmidt R, Schippers JH (2015) ROS-mediated redox signaling during cell differentiation in plants. Biochim Biophys Acta 1850(8):1497-1508. https://doi.org/10.1016/j.bbagen.2014. 12.020

73. Selosse MA, Baudoin E, Vandenkoornhuyse P (2004) Symbiotic microorganisms, a key for ecological success and protection of plants. C R Biol 327(7):639-648. https://doi.org/10.1016/j. crvi.2003.12.008

74. Seneviratne $M$, Seneviratne $G$, Madawala $H$, Vithanage $M$ (2017) Role of rhizospheric microbes in heavy metal uptake by plants. In: Singh J, Seneviratne G (eds) Agro-environmental sustainability. Springer, Cham

75. Sessitsch A, Kuffner M, Kidd P, Vangronsveld J, Wenzel WW, Fallmann K, Puschenreiter M (2013) The role of plant-associated bacteria in the mobilization and phytoextraction of trace elements in contaminated soils. Soil Biol Biochem 60(100):182-194. https://doi.org/10.1016/j.soilbio.2013.01. 012

76. Shah MP (2021) Removal of refractory pollutants from wastewater treatment plants. CRC Press, Boca Raton

77. Singh BK, Liu H, Trivedi P (2020) Eco-holobiont: a new concept to identify drivers of host-associated microorganisms. Environ Microbiol 22(2):564-567. https://doi.org/10.1111/1462-2920. 14900

78. Spaepen S, Vanderleyden J (2011) Auxin and plant-microbe interactions. Cold Spring Harb Perspect Biol 3(4):a001438. https://doi.org/10.1101/cshperspect.a001438

79. Sriprang R, Hayashi M, Yamashita M, Ono H, Saeki K, Murooka Y (2002) A novel bioremediation system for heavy metals using the symbiosis between leguminous plant and genetically engineered rhizobia. J Biotechnol 99(3):279-293. https://doi.org/10. 1016/s0168-1656(02)00219-5

80. Steinkellner S, Mammerler R (2007) Effect of flavonoids on the development of Fusarium oxysporum f. sp. Iycopersici. J Plant Interact 2(1):17-23. https://doi.org/10.1080/174291407014093 52

81. Suslow TV, Schroth MN (1982) Rhizobacteria of Sugarbeet: Effects of Seed Application and Root Colonization on Yield. Phytopathology 72:199-206. https://doi.org/10.1094/Phyto-72-199

82. Trivedi P, Pandey A (2008) Plant growth promotion abilities and formulation of Bacillus megaterium strain B 388 (MTCC6521) isolated from a temperate Himalayan location. Indian J Microbiol 48(3):342-347. https://doi.org/10.1007/s12088-008-0042-1

83. Ullah A, Mushtaq $\mathrm{H}$, Ali H, Munis MF, Javed MT, Chaudhary HJ (2015) Diazotrophs-assisted phytoremediation of heavy metals: a novel approach. Environ Sci Pollut Res Int 22(4):2505-2514. https://doi.org/10.1007/s11356-014-3699-5

84. van Dillewijn P, Nojiri H, Van der Meer JR, Wood TK (2009) Bioremediation, a broad perspective. Microb Biotechnol 2(2):125127. https://doi.org/10.1111/j.1751-7915.2009.00091.x

85. Verbon EH, Liberman LM (2016) Beneficial microbes affect endogenous mechanisms controlling root development. Trends Plant Sci 21(3):218-229. https://doi.org/10.1016/j.tplants.2016. 01.013

86. Verma JP, Jaiswal DK (2016) Book review: advances in biodegradation and bioremediation of industrial waste. Front Microbiol. https://doi.org/10.3389/fmicb.2015.01555

87. Verma S, Kuila A (2019) Bioremediation of heavy metals by microbial process. Environ Technol Innov. https://doi.org/10. 1016/j.eti.2019.100369

88. Vodnik D, Grcman H, Macek I, van Elteren JT, Kovacevic M (2008) The contribution of glomalin-related soil protein to $\mathrm{Pb}$ and $\mathrm{Zn}$ 
sequestration in polluted soil. Sci Total Environ 392(1):130-136. https://doi.org/10.1016/j.scitotenv.2007.11.016

89. Weast RC (1984) CRC handbook of chemistry and physics, 64th edn. CRC, Boca Raton

90. Yang T, Chen M-L, Wang J-H (2015) Genetic and chemical modification of cells for selective separation and analysis of heavy metals of biological or environmental significance. TrAC Trends Anal Chem 66:90-102. https://doi.org/10.1016/j.trac.2014.11. 016

91. Zhang H, Xie X, Kim MS, Kornyeyev DA, Holaday S, Pare PW (2008) Soil bacteria augment Arabidopsis photosynthesis by decreasing glucose sensing and abscisic acid levels in planta. Plant J 56(2):264-273. https://doi.org/10.1111/j.1365-313X. 2008.03593.x
92. Zhou Q, Chen Y, Yang M, Li W, Deng L (2013) Enhanced bioremediation of heavy metal from effluent by sulfate-reducing bacteria with copper-iron bimetallic particles support. Bioresour Technol 136:413-417. https://doi.org/10.1016/j.biortech.2013. 03.047

Publisher's Note Springer Nature remains neutral with regard to jurisdictional claims in published maps and institutional affiliations. 